\title{
SLIT-ROBO Rho GTPase-Activating Protein 2
}

National Cancer Institute

\section{Source}

National Cancer Institute. SLIT-ROBO Rho GTPase-Activating Protein 2. NCI Thesaurus.

Code C131602.

SLIT-ROBO Rho GT Pase-activating protein 2 (1071 aa, $121 \mathrm{kDa}$ ) is encoded by the human SRGAP2 gene. This protein is involved in cell differentiation, cell migration and neuronal morphogenesis. 